УДК $581: 576.5$ : 634.224

UDC $581: 576.5: 634.224$

DOI 10.30679/2219-5335-2022-1-73-188-202

DOI 10.30679/2219-5335-2022-1-73-188-202

ИЗМЕНЕНИЯ

УГЛЕВОДНОГО МЕТАБОЛИЗМА

ВИНОГРАДНОЙ ЛОЗЫ

В СВЯЗИ С ЗИМОСТОЙКОСТЬЮ1

Ненько Наталия Ивановна

д-р с.-х. наук, профессор

главный научный сотрудник

лаборатории физиологии

и биохимии растений

e-mail: nenko.nataliya@yandex.ru

Киселева Галина Константиновна

канд. биол. наук

старший научный сотрудник

лаборатории физиологии

и биохимии растений

e-mail: galina-kiseleva-1960@mail.ru

Ильина Ирина Анатольевна

д-р техн. наук, профессор

заместитель директора по науке

e-mail:kubansad@kubannet.ru

Соколова Виктория Викторовна

канд. с.-х. наук

заведующая научно-образовательным

сектором

e-mail: KudryshovaVV@yandex.ru

Запорожец Наталья Михайловна

канд. с-х. наук

учёный секретарь

e-mail: nat_zaporozhec@mail.ru

Караваева Алла Витальевна

младший научный сотрудник

лаборатории физиологии

и биохимии растений

e-mail: alla.karavaeva.65@mail.ru

Схаляхо Татьяна Вячеславовна

младший научный сотрудник

лаборатории физиологии

и биохимии растений

e-mail:_tShalyho@mail.ru

\title{
CHANGES \\ IN CARBOHYDRATE METABOLISM OF VINE DUE TO WINTER HARDINESS ${ }^{1}$
}

\author{
Nenko Nataliya Ivanovna \\ Dr. Sci. Agr., Professor \\ Chief Research Associate \\ of Plant Physiology \\ and Biochemistry Laboratory \\ e-mail: nenko.nataliya@yandex.ru \\ Kiseleva Galina Konstantinovna \\ Cand. Biol. Sci. \\ Senior Research Associate \\ of Plant Physiology \\ and Biochemistry Laboratory \\ e-mail: galina-kiseleva-1960@mail.ru \\ Ilina Irina Anatolyevna \\ Dr. Sci. Tech., Professor \\ Deputy Chief for Science \\ e-mail: kubansad@kubannet.ru \\ Sokolova Viktoria Viktorovna \\ Cand. Agr. Sci. \\ Head of Scientific \\ Educational Sector \\ e-mail: KudryshovaVV@yandex.ru \\ Zaporozhets Natalia Mikhailovna \\ Cand. Agr. Sci. \\ Scientific Secretary \\ e-mail: nat_zaporozhec@mail.ru
}

Karavaeva Alla Vital'evna

Junior Research Associate

of Plant Physiology

and Biochemistry Laboratory

e-mail: alla.karavaeva.65@mail.ru

Shalyakho Tatiana Vyacheslavovna

Junior Research Associate

of Plant Physiology

and Biochemistry Laboratory

e-mail: tShalyho@mail.ru

\footnotetext{
1 Исследование выполнено при финансовой поддержке Кубанского научного фонда в рамках научного проекта № МФИ-20.1/19

1 The research was carried out with the financial support of the Kuban Science Foundation in the framework of the scientific project № MFI-20.1/19
} 
Федеральное государственное бюджетное научное учреждение «Северо-Кавказский федеральный научный иентр садоводства, виноградарства, виноделия», Краснодар, Россия

В важном регионе возделывания винограда - Анапо-Таманской зоне Краснодарского края, проблема его адаптационной устойчивости в нестабильных климатических условиях является актуальной. Цель данной работы - провести сравнительные исследования сортов винограда различного эколого-географического происхождения о динамике содержания крахмала и водорастворимых сахаров в условиях осенне-зимнего периода, выделить зимостойкие сорта по этому показателю. Объекты исследований - сорта винограда различного эколого-географического происхождения: Кристалл (контроль) евро-амуро-американского происхождения; Красностоп АЗОС, Достойный евро-американского происхождения; Восторг - амуро-американского происхождения; Зариф восточно-европейского происхождения; Алиготе - западно-европейского происхождения. Выявлены адаптационные перестройки углеводного метаболизма, возникающие в ответ на нестабильные климатические условия осенне-зимнего периода 2020-2021 гг. Установлено, что у сортов Достойный, Красностоп АЗОС, Зариф накопление крахмала сыграло важную роль в адаптационных процессах во время перезимовки, его содержание уменьшилось в 10,38; 9,63 и 8,75 раз соответственно. Показано, что у сортов Достойный, Восторг, Алиготе водорастворимые сахара сыграли важную роль в устойчивости к зимним стрессовым условиям, их содержание в почках увеличилось в 1,2-1,5 раз после низкотемпературного воздействия. Выявлена важная роль осмопротектора сахарозы в формировании защитного ответа у сортов Достойный и Восторг, содержание которой в почках и побегах увеличилось в 4,8-6,3 раз после действия низких температур.
Federal State Budget

Scientific Institution

«North Caucasian Federal

Scientific Center of Horticulture,

Viticulture, Wine-making»,

Krasnodar, Russia

The problem of grape's adaptive stability in unstable climatic conditions in the important region of grape cultivation - the Anapo-Taman zone of the Krasnodar region, is relevant. The purpose of this work is to conduct comparative studies of grape varieties of various ecological and geographical origin on the dynamics of the content of starch and water-soluble sugars in the conditions of the autumn-winter period, to identify winterhard varieties according to this indicator. The objects of research are grape varieties of various ecological and geographical origin: Kristall (control - Euro-Amur-American origin; Krasnostop AZOS, Dostoynyi Euro-American origin; Vostorg Amur-American origin; Zarif Eastern European origin; Aligote Western European origin. Adaptive rearrangements of carbohydrate metabolism arising in response to unstable climatic conditions of the autumn-winter period of 2020-2021 are revealed. It was found that in the varieties Dostoynyi, Krasnostop AZOS, Zarif, the accumulation of starch played an important role in the adaptation processes during overwintering, its content decreased by $10,38,9.63$ and 8.75 times, respectively. It is shown that in the varieties Dostoynyi, Vostorg, Aligote, water-soluble sugars played an important role in resistance to winter stress conditions, the content of which in the buds increased by 1.2-1.5 times after low-temperature exposure. An important role of the osmoprotector of sucrose in the formation of a protective response in varieties Dostoynyi and Vostorg was revealed, the content of which in the buds and shoots increased by 4.8-6.3 times after the action of low temperatures. 
По результатам исследований содержания крахмала и растворимых сахаров выявлено, что наибольшим потенциалом устойчивости к зимним стрессам обладает сорт Достойный; сорт Восторг выделился как наиболее адаптивный по содержанию водорастворимых сахаров, в том числе и сахарозы.

Ключевые слова: ВИНОГРАД, ЗИМОСТОЙКОСТЬ, АДАПТАЦИОННАЯ УСТОЙЧИВОСТЬ, КРАХМАЛ, ВОДОРАСТВОРИМЫЕ САХАРА
According to the results of studies of the content of starch and soluble sugars, it was revealed that Dostoynyi variety has the greatest potential for resistance to winter stresses; Vostorg variety stood out as the most adaptive in terms of the content of water-soluble sugars, including sucrose.

Key words: GRAPES, WINTER HARDINESS, ADAPTIVE STABILITY, STARCH, WATER-SOLUBLE SUGAR

Введение. Содержание углеводов в органах растений - важный показатель, характеризующий изменение метаболических процессов как в процессе подготовки растений к зиме, так и во время перезимовки. Физиолого-биохимические превращения, происходящие в органах и тканях виноградного растения в течение вегетационного периода, в значительной степени обеспечивают их зимостойкость. Ассимиляты, образовавшиеся в течение лета, виноград использует на поддержание жизненных процессов и вегетативный рост. Значительную долю продуктов ассимиляции виноград, как и большинство других древесных растений, накапливает в древесине, сердцевинных лучах и клетках коры в виде запасных веществ, преимущественно углеводов (крахмала, сахаров), гемицеллюлоз и др. [1-5].

Крахмал является основным запасным веществом тканей и органов многих растений, количество которого увеличивается к концу лета и началу осени. Зимой под действием низких температур происходит гидролиз крахмала с образованием водорастворимых сахаров, таких как сахароза, глюкоза, фруктоза. Известно, что сахара играют полифункциональную роль в низкотемпературной адаптации растений, обладая осморегуляторными, антифризными, криопротекторными, антиоксидантными свойствами.

Сахара, накапливаемые в большом количестве в клетках растений, действуют, прежде всего, как осмолиты для поддержания клеточного гомеостаза. В результате повышения общего содержания сахаров, точка замерза- 
ния содержимого клеток снижается (антифризная функция), и образование льда происходит в межклетниках. При этом протопласт постепенно обезвоживается, что препятствует внутриклеточному образованию льда [6, 7].

В последнее время появились работы, в которых подтверждается антиоксидантная роль сахаров, участвующих в снижении уровня окислительного стресса, вызванного низкими температурами [8]. Помимо вышеперечисленных функций, сахара рассматриваются как мессенджеры, участвующие в управлении экспрессией генов (сигнальная функция), вовлеченных в регуляцию фотосинтеза, роста и расходования энергетических ресурсов [9].

Клетки тканей виноградного растения в зимний период подвергаются угрозе обезвоживания внеклеточным льдом, во избежание этого в процессе низкотемпературной адаптации растения накапливают большое количество водорастворимых сахаров. Показано, что в условиях Турции и Ирана у морозостойких сортов винограда при действии низких температур усиливается гидролиз крахмала и происходит накопление растворимых сахаров, с содержанием которых отрицательно коррелирует гибель почек [10-12].

Зимостойкость корнесобственных растений Vitis amurensis Rupr. из Китайской Национальной коллекции генетических ресурсов винограда коррелировала с общим содержанием растворимых сахаров в побегах [13].

В условиях Анапо-Таманской зоны Краснодарского края увеличение содержания водорастворимых сахаров происходило с ноября по январь, затем содержание этих углеводов начало снижаться, что свидетельствует об активном их участии в защитной функции от замерзания [14-16].

Принимая во внимание многочисленные защитные функции крахмала и сахаров, в связи с продолжающимся изучением адаптационных механизмов устойчивости, поиском диагностических показателей зимостойкости, данные исследования представляются актуальными. Физиологобиохимические исследования регионального сортимента винограда дают 
возможность проследить адаптационные перестройки углеводного метаболизма, возникающие в ответ на нестабильные климатические условия.

Цель данной работы - провести сравнительные исследования сортов винограда различного эколого-географического происхождения по динамике содержания крахмала и водорастворимых сахаров в условиях осеннезимнего периода, выделить зимостойкие сорта по этому показателю.

Объекты и методы исследований. Исследования проводились в 2020-2021 гг. на базе ампелографической коллекции ФГБНУ АЗОСВиВ, расположенной в г. Анапа, квартал технических сортов винограда на черноземе южном карбонатном. Растения 1995 года посадки, подвой Кобер 5ББ. Формировка - двусторонний высокоштамбовый спиральный кордон АЗОС. Схема посадки 3 х 2,5 м. Лабораторные исследования выполнялись в центре коллективного пользования ФГБНУ СКФНЦСВВ.

Объектами исследований являлись сорта и межвидовые гибриды винограда различного эколого-географического происхождения: Кристалл (контроль) - евро-амуро-американского происхождения; Красностоп АЗОС, Достойный - евро-американского происхождения; Восторг - амуро-американского происхождения; Зариф - восточноевропейского происхождения; Алиготе - западноевропейского происхождения.

Исследования проводили в 3-кратной повторности, каждая повторность состояла из 10 почек или кусочков однолетних побегов. Содержание крахмала и растворимых сахаров определяли согласно методике [17] с использованием антронового реактива по спектру поглощения (длина волны 670 нм), снятому на фотоколориметре ФЭК-56.

Определение активности пероксидазы проводили по модифицированному методу Бояркина, основанному на определении скорости реакции окисления бензидина под действием фермента, содержащегося в тканях, за определенный промежуток времени (1 мин) [18]. При моделировании низ- 
котемпературного стресса (температура $-20{ }^{\circ} \mathrm{C}$ ) использовали шкаф холодильный Gronland. Полученные экспериментальные данные обрабатывали с помощью общепринятых методов вариационной статистики [19].

Обсуждение результатов. Вхождение винограда в состояние зимнего покоя, период закаливания проходили в благоприятных условиях (рис. 1).

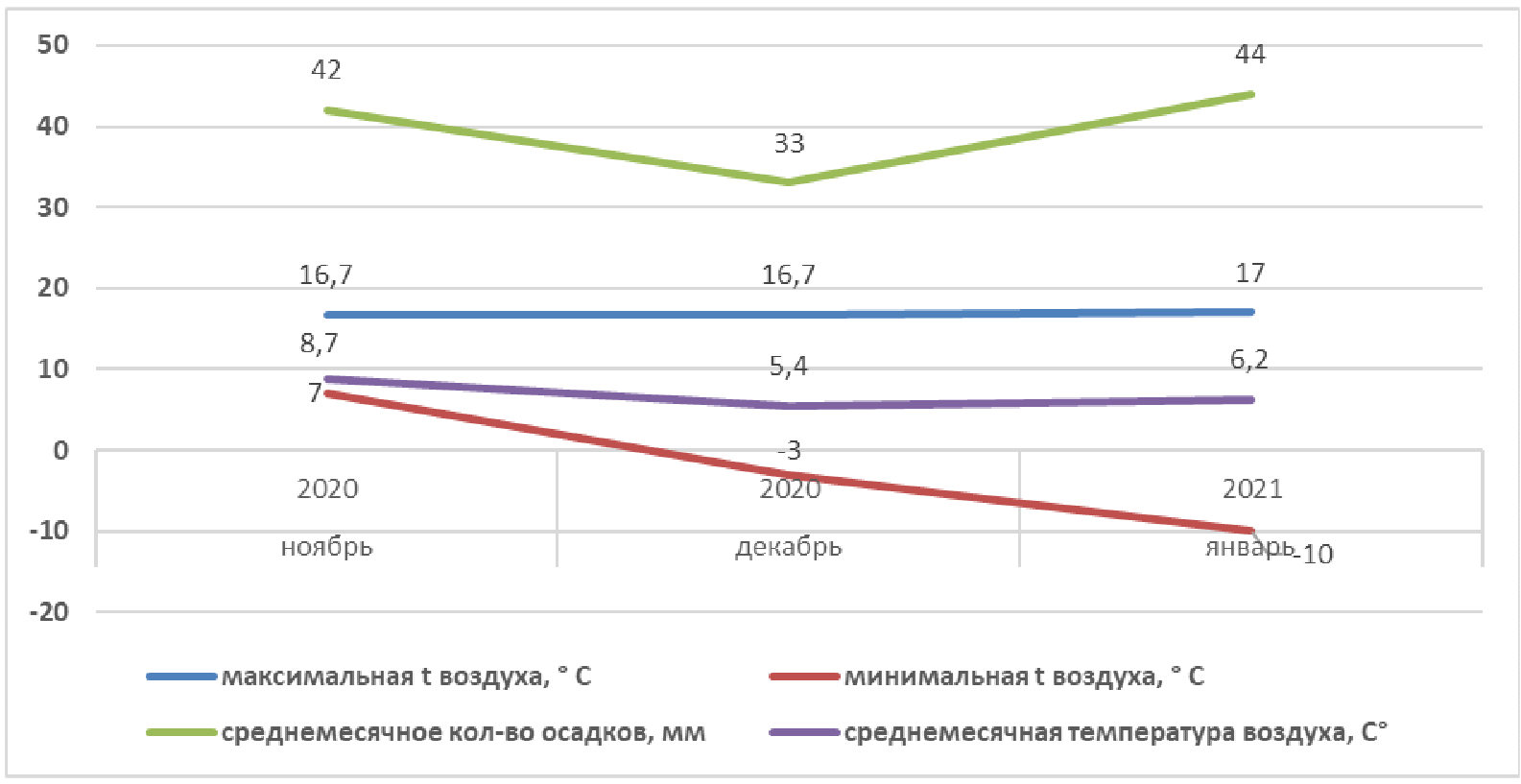

Рис. 1. Гидротермические условия ампелографической коллекции ФГБНУ АЗОСВиВ в осенне-зимний период 2020-2021 гг. (г.-к. Анапа)

За изучаемый осенне-зимний период в ноябре 2020 г. максимальная температура воздуха составляла от $+16,7^{\circ} \mathrm{C}$, минимальная температура воздуха $+7^{\circ} \mathrm{C}$, среднемесячная $8,7^{\circ} \mathrm{C}$. В декабре 2020 г. максимальная температура воздуха составляла $+16,7^{\circ} \mathrm{C}$, минимальная температура воздуха $-3{ }^{\circ} \mathrm{C}$, среднемесячная 5,4 ${ }^{\circ} \mathrm{C}$. В январе 2021 г. максимальная температура воздуха достигала $+17^{\circ} \mathrm{C}$, минимальная $-10^{\circ} \mathrm{C}$, среднемесячная $6,2^{\circ} \mathrm{C}$. Среднемесячное количество осадков составляло 42 мм, 33 мм, 44 мм соответственно.

К началу зимнего периода микроскопирование показало полное вызревание тканей виноградной лозы: перидермы, вторичной флоэмы, камбия, вторичной ксилемы, сердцевины. В различных тканях отложилось большое количество крахмальных зерен (рис. 2). 


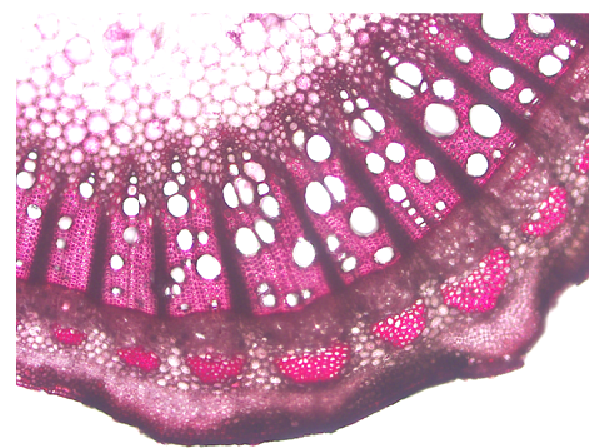

A

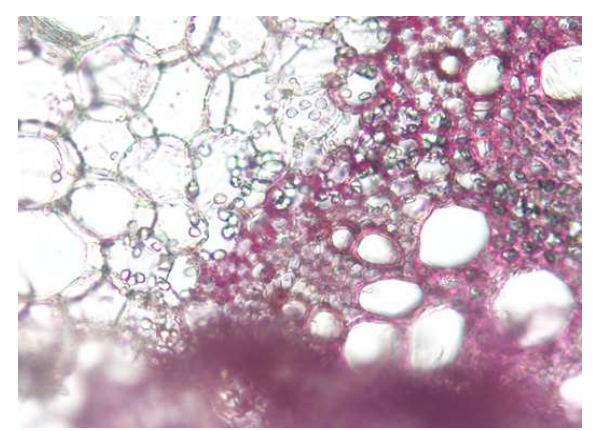

Б

Рис. 2. А - Микрофото поперечного среза годичного побега винограда сорта Кристалл (увеличение $4 \times 10$, окраска основным фуксином); Б - крахмальные зерна в перимедуллярной зоне побега в ноябре 2020 г. (увеличение $10 \times 40$, окраска основным фуксином).

В ноябре содержание крахмала в побеге составляло 5,85-16,84 мг/г сухого веса в зависимости от сорта. Наибольшие количества крахмала обнаружены у сортов Кристалл, Алиготе, Зариф. В январе его содержание у всех сортов уменьшилось в связи с гидролизом и превращением в растворимые сахара, причем в большей степени у сортов Достойный, Красностоп АЗОС, Зариф: у сорта Достойный - в 10,38 раз, у сортов Красностоп АЗОС и Зариф - в 9,63 и 8,75 раз соответственно (рис. 3).

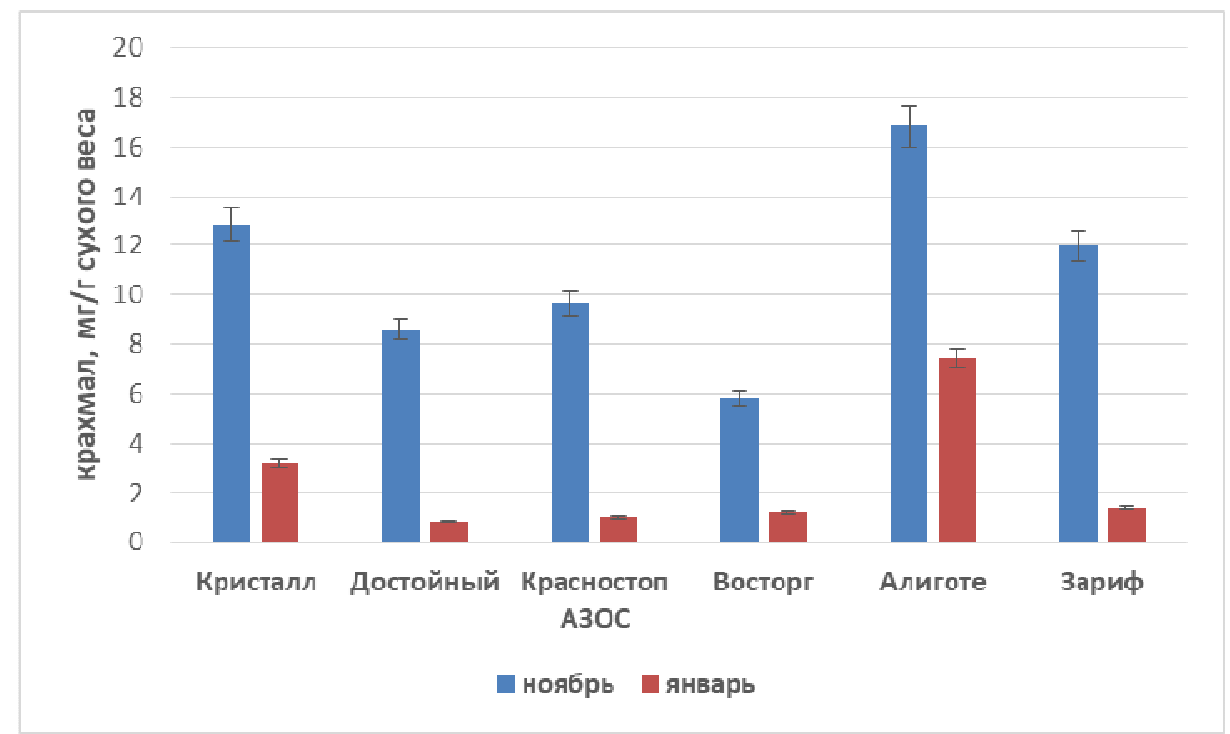

Рис. 3. Содержание крахмала в побегах винограда в осенне-зимний период 2020-2021 гг. $\mathrm{HCP}{ }_{0,5}$ : ноябрь - 0,51; январь - 1,24. 
Таким образом, у этих сортов накопление крахмала сыграло важную роль в адаптационных процессах во время перезимовки.

Наряду с крахмалом виноград накопил растворимые сахара в тканях почек и побегов. Содержание суммы водорастворимых сахаров (сахарозы, глюкозы, фруктозы) в ноябре в почках варьировало от 1,73 мг/г сухого веса у сорта Алиготе до 4,93 мг/г сухого веса у сорта Кристалл.

Содержание сахаров в побегах было значительно больше, чем в почках - в 2,3-4,6 раз, за исключением сорта Кристалл, у которого оно имело почти одинаковые количественные показатели. Содержание сахаров в побегах варьировало от 4,66 мг/г сухого веса у сорта Кристалл до 11,24 мг/г сухого веса у сорта Достойный (табл. 1).

Таблица 1 - Содержание растворимых сахаров в вегетативных органах винограда в течение зимнего периода 2020-2021 гг. (мг/г сухого веса)

\begin{tabular}{|l|c|c|c|c|}
\hline \multirow{2}{*}{\multicolumn{1}{c|}{ Сорт }} & \multicolumn{2}{|c|}{ Ноябрь 2020 г. } & \multicolumn{2}{c|}{ Январь 2021} \\
\cline { 2 - 5 } & почки & побег & почки & побег \\
\hline Кристалл & $4,93+0,22$ & $4,66 \pm 0,11$ & $2,50 \pm 0,15$ & $9,51 \pm 0,43$ \\
\hline Достойный & $3,83 \pm 1,03$ & $11,24 \pm 1,44$ & $5,80 \pm 1,75$ & $4,58 \pm 0,42$ \\
\hline Красностоп АЗОС & $4,20 \pm 1,53$ & $9,56 \pm 0,29$ & $2,00 \pm 0,15$ & $9,63 \pm 0,04$ \\
\hline Восторг & $3,43 \pm 0,43$ & $10,34 \pm 0,73$ & $4,43 \pm 0,79$ & $11,62 \pm 0,75$ \\
\hline Алиготе & $1,73 \pm 0,32$ & $7,99 \pm 0,99$ & $2,10 \pm 0,45$ & $5,85 \pm 0,26$ \\
\hline Зариф & $2,17 \pm 0,12$ & $9,36 \pm 2,13$ & $2,10 \pm 0,26$ & $11,84 \pm 0,20$ \\
\hline НСР & 1,17 & 2,24 & 1,53 & 2,89 \\
\hline
\end{tabular}

По литературным данным, в северных областях Ирана, где зимние температуры достигают $-22{ }^{\circ} \mathrm{C}$, а изредка $-30{ }^{\circ} \mathrm{C}$, увеличение содержания растворимых сахаров в почках винограда происходило с ноября по январь, когда их максимальное содержание наблюдали у морозостойких сортов [12].

В наших исследованиях увеличение содержания растворимых сахаров в январе наблюдали не у всех сортов. Данный факт, возможно, объясняется тем, что гидролиз крахмала у некоторых сортов сдерживался недостаточно низкими температурами в данном регионе, которые достигали в январе 2021 года $-10{ }^{\circ} \mathrm{C}$. 
У сортов Достойный, Восторг, Алиготе содержание сахаров в почках увеличилось в 1,2-1,5 раз в сравнении с ноябрем. Следовательно, у этих сортов водорастворимые сахара сыграли важную роль в формировании устойчивости к зимним стрессовым условиям, поскольку известно, что при холодовом стрессе растворимые сахара повышают осмотический потенциал цитоплазмы и понижают точку замерзания [11].

В побегах выше указанных сортов (Достойный, Восторг, Алиготе) содержание сахаров, наоборот, уменьшилось в 1,3-2,5 раз или осталось на прежнем уровне ноября. У сортов Кристалл и Красностоп АЗОС содержание сахаров в почках уменьшилось примерно в 2 раза, зато в побегах увеличилось в сравнении с ноябрем.

Таким образом, у одних сортов устойчивость к зимним условиям достигалась увеличением сахаров в почках, у других - в побегах. Ко всему сказанному нужно учитывать тот факт, что не все сахара задействованы в процессе адаптации к неблагоприятным факторам, поскольку поддерживаются два пула сахаров: один - для конститутивных потребностей клеток, другой - для обеспечения устойчивости [20].

Таким образом, по результатам исследований содержания крахмала и растворимых сахаров сорта Достойный, Красностоп АЗОС, Зариф обладают большим потенциалом устойчивости к зимним стрессам в сравнении с другими изучаемыми сортами.

В зимний период растворимый углевод сахароза быстро включается в метаболические процессы винограда в качестве протекторного соединения. Сахароза, являясь осмотически активным соединением, способствует понижению температуры льдообразования в тканях виноградной лозы и снижению повреждений [12].

Содержание сахарозы в ноябре в почках варьировало от 0,27 мг/г сухого веса у сорта Алиготе до 1,07 мг/Г сухого веса у сорта Восторг (табл. 2). Содержание сахарозы в ноябре в побегах было значительно больше, чем в почках - в 3,5-10,8 раз, за исключением сорта Восторг, у ко- 
торого оно имело почти одинаковые количественные показатели. Содержание сахарозы в побегах варьировало от 1,57 мг/Г сухого веса у сорта Восторг до 5,08 мг/г сухого веса у сорта Достойный.

Таблица 2 - Содержание сахарозы в вегетативных органах винограда в течение зимнего периода 2020-2021 гг. (мг/г сухого веса)

\begin{tabular}{|l|c|c|c|c|}
\hline \multirow{2}{*}{\multicolumn{1}{|c|}{ Сорт }} & \multicolumn{2}{|c|}{ Ноябрь 2020 г. } & \multicolumn{2}{c|}{ Январь 2021 г. } \\
\cline { 2 - 5 } & почки & побег & почки & побег \\
\hline Кристалл & $0,70 \pm 0,15$ & $2,86 \pm 0,21$ & $0,40 \pm 0,20$ & $7,54 \pm 0,28$ \\
\hline Достойный & $0,47 \pm 0,12$ & $5,08 \pm 0,27$ & $2,27 \pm 0,70$ & $3,48 \pm 0,35$ \\
\hline Красностоп АЗОС & $0,97 \pm 0,26$ & $3,42 \pm 0,08$ & $1,23 \pm 0,15$ & $8,16 \pm 0,16$ \\
\hline Восторг & $1,07 \pm 0,30$ & $1,57 \pm 0,18$ & $1,90 \pm 0,35$ & $9,98 \pm 0,36$ \\
\hline Алиготе & $0,27 \pm 0,03$ & $1,89 \pm 0,14$ & $0,60 \pm 0,35$ & $3,18 \pm 0,25$ \\
\hline Зариф & $0,60 \pm 0,10$ & $4,1 \pm 0,25$ & $0,70 \pm 0,15$ & $9,68 \pm 0,10$ \\
\hline НСР $_{05}$ & 0,29 & 1,28 & 0,73 & 2,88 \\
\hline
\end{tabular}

В январе содержание сахарозы в почках увеличилось в 1,2-4,8 раза в сравнении с ноябрем у всех изучаемых сортов, кроме сорта Кристалл. В большей степени содержание сахарозы увеличилось в почках сорта Достойный - в 4,8 раза, свидетельствующее о ее важном вкладе в формирование защитного ответа на низкие температуры.

В январе содержание сахарозы в побегах всех изучаемых сортов винограда также увеличилось в 1,7-6,3 раза, кроме сорта Достойный. В большей степени содержание сахарозы увеличилось в побегах сорта Восторг - в 6,3 раза, свидетельствующее о ее значимости при адаптации к зимним стрессам.

Итак, по содержанию осмопротектора сахарозы в побегах и почках сорта Достойный, Восторг обладают большим потенциалом устойчивости к зимним стрессам в сравнении с другими изучаемыми сортами.

В зимний период из-за обезвоживания клеток растений внеклеточным льдом прекращается интенсивность поглощения кислорода и дыхательный коэффициент снижается в несколько раз [6]. Для большинства растений ключевыми субстратами дыхания является крахмал и сахароза. 
Некоторыми исследователями прослеживается зависимость между динамикой содержания крахмала и активностью пероксидазы. Высокая активность пероксидазы в зимнее время связана с нарушением процесса дыхания, и у недостаточно зимостойких сортов плодовых активность пероксидазы повышается после зимних повреждений, т. е. играет защитную роль в обезвреживании токсических веществ [21].

В наших исследованиях изменение дыхательного метаболизма при низких температурах наблюдали в эксперименте по искусственному промораживанию побегов винограда по показателю активности пероксидазы. Выявлено, что у сорта Кристалл после проморозки активность пероксидазы почти не изменилась, у сортов Достойный и Алиготе - уменьшилась в 2,3 и 4,9 раза соответственно, свидетельствующее об их высокой морозостойкости.

Сорта Красностоп АЗОС, Восторг, Зариф по показателю активности пероксидазы после низкотемпературного воздействия проявили себя недостаточно устойчивыми. У сортов Красностоп АЗОС активность пероксидазы увеличилась в 1,3 раза, у сортов Восторг, Зариф - в 1,4 раза (рис. 5).

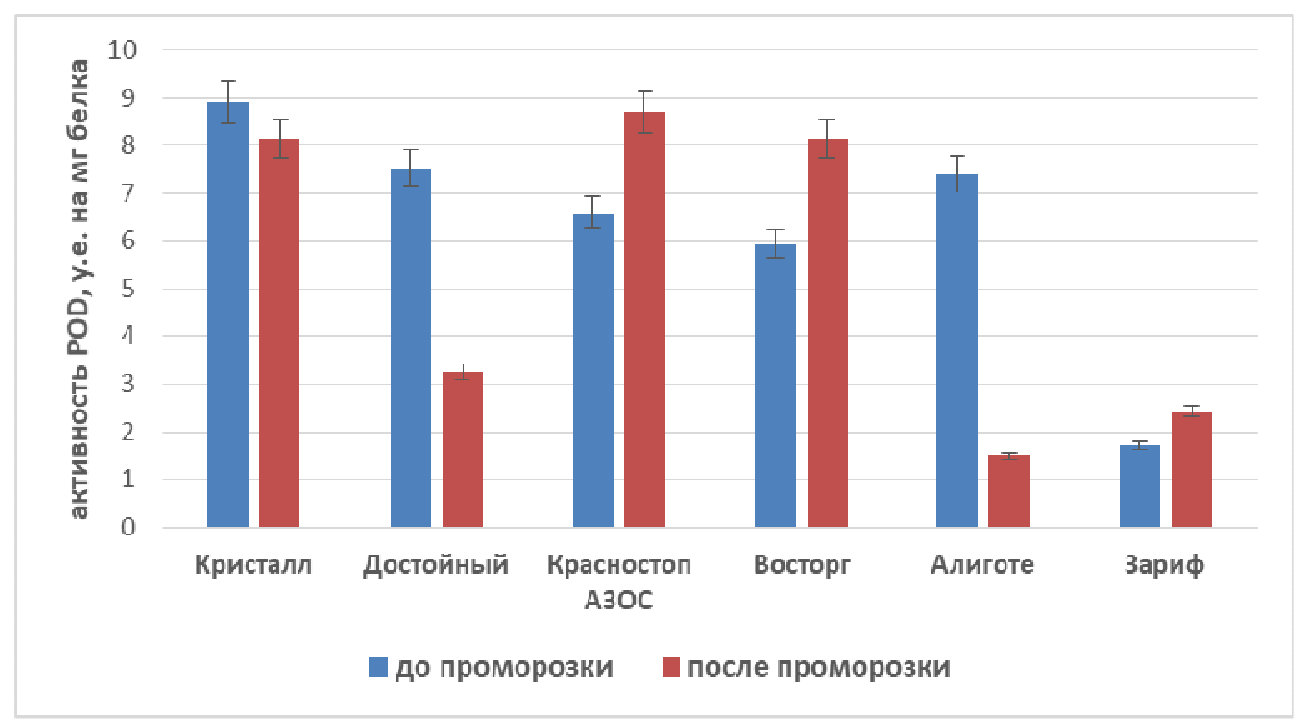

Рис. 5. Активность пероксидазы в побеге винограда в эксперименте по искусственному промораживанию, январь 2021 г. $\mathrm{HCP}_{0,5}$ : ноябрь - 0,55; январь - 1,52. 
Bbыводы. Проведены сравнительные физиолого-биохимические исследования сортов винограда различного эколого-географического происхождения по динамике содержания крахмала и водорастворимых сахаров в условиях осенне-зимнего периода 2020-2021 гг. Подтвержден ранее установленный факт вовлеченности углеводов механизм защиты растений от неблагоприятных зимних условий. Выявлены адаптационные перестройки углеводного метаболизма, возникающие в ответ на нестабильные климатические условия.

Установлено, что у сортов Достойный, Красностоп АЗОС, Зариф накопление крахмала сыграло важную роль в адаптационных процессах во время перезимовки, его содержание уменьшилось в 10,38; 9,63 и 8,75 раза соответственно. Показано, что у сортов Достойный, Восторг, Алиготе водорастворимые сахара сыграли важную роль в устойчивости к зимним стрессовым условиям, содержание которых в почках увеличилось в 1,2-1,5 раза после низкотемпературного воздействия. Выявлена важная роль осмопротектора сахарозы в формирование защитного ответа у сортов Достойный и Восторг, содержание которой в почках и побегах увеличилось в 4,8-6,3 раз после действия низких температур. Активность пероксидазы в побегах винограда имела тесную связь с содержанием крахмала.

По результатам исследований содержания крахмала и растворимых сахаров выявлено, что наибольшим потенциалом устойчивости к зимним стрессам обладает сорт Достойный; сорт Восторг выделился как наиболее адаптивный по содержанию водорастворимых сахаров, в том числе и сахарозы. Изучение динамики содержания углеводов в виноградной лозе в течение зимнего периода позволяет получить надежную оценку генотипов винограда на устойчивость к нестабильным погодно-климатическим условиям зимнего периода и могут быть использованы в качестве косвенных методов диагностики сортов на зимостойкость. 


\section{Литература}

1. Antivilo F.G., Paz R.C., Echeverria M., Keller M. Thermal history parameters drive changes in physiology and cold hardiness of young grapevine plants during winter / Agricultural and Forest Meteorology. - 2018. - № 262(15). - P. 227-236. doi. https://doi.org/10.1016/j.agrformet.2018.07.017.

2. Smolova T., Khorobrykh A., Savchenko T. Cortical photosynthesis as a physiological marker for grape breeding: Methods and approaches / Les Ulis: EDP BIO Web of Conferences. - 2020. - T. 25. doi: https://doi.org/10.1051/bioconf/20202502018.

3. Красова Н.Г., Голышкина Л.В., Макаркина М.А. Динамика содержания углеводов в побегах сортов яблони различной зимостойкости // Плодоводство и ягодоводство России. 2001. Т. 28. № 1. С. 308-315.

4. Călugăr A., Cordea M.I., Babeş A., Fejer M. Dynamics of Starch Reserves in Some Grapevine Varieties (Vitis vinifera L.) During Dormancy / BulletinUASVM Horticulture. 2019. - № 76(2). - P. 185-192. DOI:10.15835/buasvmcn-hort: 2019.0008.

5. Fernandez E., Cuneo I.F., Luedeling E., Alvarado L., Farias D., Saa S. Starch and hexoses concentrations as physiological markers in dormancy progression of sweet cherry twigs / Trees. - 2019. - №33. - P.1187-1201 https://doi.org/10.1007/s00468-019-01855-0.

6.Трунова Т.И. Растение и низкотемпературный стресс / Отв. ред. Вл. В. Кузнецов. Ин-т физиологии растений им. К.А. Тимирязева РАН. М.: Наука, 2007. 54 с.

7. Rosa M., Prado C., Podazza G., Interdonato R., González J.A., Hilal M., Prado F.E. Soluble sugars-Metabolism, sensing and abiotic stress: A complex network in the life of plants / Plant Signal Behav. - 2009. - № 4 (5). - P. 388-393. doi:10.4161/psb.4.5.8294.

8. Колупаев Ю.Е., Карпец Ю.В. Формирование адаптивных реакций на действие абиотических стрессоров. К: Основа, 2010. 352 с.

9. Bolouri $\square$ Moghaddam M.R., Le Roy K., Xiang L., F. Rolland, W. Van den Ende Sugar signalling and antioxidant network connections in plant cells / The FEBS Journal. 2010. - № 277(9). - P. 2022-2037. doi:10.1111/j.1742-4658.2010.07633.x.

10. Kaya Ö. Bud Death and Its Relationship with Lateral Shoot, Water Content and Soluble Carbohydrates in Four Grapevine Cultivars Following Winter Cold / ErwerbsObstbau. - 2020. - 62 (1). - P. 43-50. https://doi.org/10.1007/s10341-020-00495-w.

11. Köse C., Kaya Ö. Determination of resistance to low temperatures of winter buds according to position in Karaerik ( V. vinifera L.) grape cultivar / International Journal of Scientific and Research Publications. - 2017. - № 7 (4). - P.64-68. doi: 10.1007/s11738-0172513-7.

12. Ershadi A., Karimi R., Naderi K. M. Freezing tolerance and its relationship with soluble carbohydrates, proline and water content in 12 grapevine cultivars / Acta physiologiae plantarum. - 2016. - № 38 (2). - P. 1-10. DOI 10.1007/s11738-015-2021-6.

13. Y. Zhao, Z.X. Wang, Y.M. Yang, H.S. Liu, G.L. Shi, J. Ai Analysis of the cold tolerance and physiological response differences of amur grape (Vitis amurensis) germplasms during overwintering / Scientia Horticulturae. - 2020. - № 259 (3). - P.108760. https://doi.org/10.1016/j.scienta.2019.108760.

14. Nenko N. I., Kisileva G. K., Ilina I. A., Petrov V.S., Shkhalyaho T.V. Study of the stability of grapes varieties of various ecological-geographic origin to the stresses of the winter period / Proceedings of the International Conference "Scientific research of the SCO countries: synergy and integration". Part 1 - Reports in English (June 24, 2020. Beijing, PRC), P. 183-191. 
15. Nataliya Nenko, Irina Ilina, Natalia Zaporozhets, Galina Kiseleva and Tatiana Skhalyakho. Studying of the resistance to winter stresses of grapevine varieties of different ecological and geographical origin / BIO Web of Conferences Volume 25 (2020) International Scientific Online-Conference "Bioengineering in the Organization of Processes Concerning Breeding and Reproduction of Perennial Crops" 2020 Krasnodar, Russia, October 6-8, 2020. DOI: https://doi.org/10.1051/bioconf/20202502015.

16. Ненько Н.И., Киселева Г.К., Ильина И.А., Соколова В.В., Запорожец Н.М. Исследование физиолого-биохимических изменений в тканях побегов винограда в зимних погодно-климатических условиях [Электронный ресурс] // Плодоводство и виноградарство Юга России. 2020. № 66(6). С. 222-236. URL: http://journalkubansad.ru/pdf/20/06/16.pdf. DOI: 10.30679/2219-5335-2020-6-66-222-236 (дата обращения: 25.11.2021).

17. Воробьев Н.В. Определение содержания сахарозы, фруктозы и глюкозы в растительных тканях с помощью антронового реактива // Бюллетень НТИ ВНИИ риса. 1985. № 33. С.11-13.

18. Методы биохимического исследования растений / А.И. Ермаков [и др.]. Л.: Агропромиздат, 1987. С. 41-45.

19. Доспехов Б.А. Методика полевого опыта (с основами статистической обработки результатов исследований). М., 1979. 463 с.

20. Колупаев Ю.Е., Горелова Е. И., Ястреб Т.О. Механизмы адаптации растений к гипотермии: роль антиоксидантной системы // Вісник Харківського національного аграрного університету. Серія біологія. 2018. № 1 (43). С. 6-33.

21. Об устойчивости яблони к неблагоприятным условиям зимнего периода / Н.Г. Красова [и др.] // Сельскохозяйственная биология. 2014. № 1. С. 42-49.

\section{References}

1. Antivilo F.G., Paz R.C., Echeverria M., Keller M. Thermal history parameters drive changes in physiology and cold hardiness of young grapevine plants during winter / Agricultural and Forest Meteorology. - 2018. - № 262(15). - P. 227-236. doi. https://doi.org/10.1016/j.agrformet.2018.07.017.

2. Smolova T., Khorobrykh A., Savchenko T. Cortical photosynthesis as a physiological marker for grape breeding: Methods and approaches / Les Ulis: EDP BIO Web of Conferences. - 2020. - T. 25. Doi: https://doi.org/10.1051/bioconf/20202502018.

3. Krasova N.G., Golyshkina L.V., Makarkina M.A. Dinamika soderzhaniya uglevodov v pobegah sortov yabloni razlichnoj zimostojkosti // Plodovodstvo i yagodovodstvo Rossii. 2001. T. 28. № 1. S. 308-315.

4. Călugăr A., Cordea M.I., Babeş A., Fejer M. Dynamics of Starch Reserves in Some Grapevine Varieties (Vitis vinifera L.) During Dormancy / BulletinUASVM Horticulture. 2019. - № 76(2). - P. 185-192. DOI:10.15835/buasvmcn-hort: 2019.0008.

5. Fernandez E., Cuneo I.F., Luedeling E., Alvarado L., Farias D., Saa S. Starch and hexoses concentrations as physiological markers in dormancy progression of sweet cherry twigs / Trees. - 2019. - №33. - P.1187-1201 https://doi.org/10.1007/s00468-019-01855-0.

6.Trunova T.I. Rastenie i nizkotemperaturnyj stress / Otv. red. Vl.V. Kuznecov. In-t fiziologii rastenij im. K.A. Timiryazeva RAN. M.: Nauka, 2007. 54 s.

7. Rosa M., Prado C., Podazza G., Interdonato R., González J.A., Hilal M., Prado F.E. Soluble sugars-Metabolism, sensing and abiotic stress: A complex network in the life of plants / Plant Signal Behav. - 2009. - № 4 (5). - P. 388-393. doi:10.4161/psb.4.5.8294

8. Kolupaev Yu.E., Karpec Yu.V. Formirovanie adaptivnyh reakcij na dejstvie abioticheskih stressorov. K: Osnova, 2010. 352 s. 
9. Bolouri $\square$ Moghaddam M.R., Le Roy K., Xiang L., F. Rolland, W. Van den Ende Sugar signalling and antioxidant network connections in plant cells / The FEBS Journal. 2010. - № 277(9). - P. 2022-2037. doi:10.1111/j.1742-4658.2010.07633.x.

10. Kaya Ö. Bud Death and Its Relationship with Lateral Shoot, Water Content and Soluble Carbohydrates in Four Grapevine Cultivars Following Winter Cold / ErwerbsObstbau. - 2020. - 62 (1). - P. 43-50. https://doi.org/10.1007/s10341-020-00495-w.

11. Köse C., Kaya Ö. Determination of resistance to low temperatures of winter buds according to position in Karaerik (V. vinifera L.) grape cultivar / International Journal of Scientific and Research Publications. - 2017. - № 7 (4). - P.64-68. doi: 10.1007/s11738-0172513-7.

12. Ershadi A., Karimi R., Naderi K. M. Freezing tolerance and its relationship with soluble carbohydrates, proline and water content in 12 grapevine cultivars / Acta physiologiae plantarum. - 2016. - № 38 (2). - P. 1-10. DOI 10.1007/s11738-015-2021-6

13. Y. Zhao, Z.X. Wang, Y.M. Yang, H.S. Liu, G.L. Shi, J. Ai Analysis of the cold tolerance and physiological response differences of amur grape (Vitis amurensis) germplasms during overwintering / Scientia Horticulturae. - 2020. - № 259 (3). - P.108760. https://doi.org/10.1016/j.scienta.2019.108760.

14. Nenko N. I., Kisileva G. K., Ilina I. A., Petrov V.S., Shkhalyaho T.V. Study of the stability of grapes varieties of various ecological-geographic origin to the stresses of the winter period / Proceedings of the International Conference "Scientific research of the SCO countries: synergy and integration". Part 1 - Reports in English (June 24, 2020. Beijing, PRC), P. 183-191.

15. Nataliya Nenko, Irina Ilina, Natalia Zaporozhets, Galina Kiseleva and Tatiana Skhalyakho. Studying of the resistance to winter stresses of grapevine varieties of different ecological and geographical origin / BIO Web of Conferences Volume 25 (2020) International Scientific Online-Conference "Bioengineering in the Organization of Processes Concerning Breeding and Reproduction of Perennial Crops" 2020 Krasnodar, Russia, October 6-8, 2020 DOI: https://doi.org/10.1051/bioconf/20202502015.

16. Nen'ko N.I., Kiseleva G.K., Il'ina I.A., Sokolova V.V., Zaporozhec N.M. Issledovanie fiziologo-biohimicheskih izmenenij $\mathrm{v}$ tkanyah pobegov vinograda $\mathrm{v}$ zimnih pogodnoklimaticheskih usloviyah [Elektronnyj resurs] // Plodovodstvo i vinogradarstvo Yuga Rossii. 2020. № 66(6). S. 222-236. URL: http://journalkubansad.ru/pdf/20/06/16.pdf. DOI: 10.30679/2219-5335-2020-6-66-222-236 (data obrashcheniya: 25.11.2021).

17. Vorob'ev N.V. Opredelenie soderzhaniya saharozy, fruktozy i glyukozy v rastitel'nyh tkanyah s pomoshch'yu antronovogo reaktiva // Byulleten' NTI VNII risa. 1985. № 33. S.11-13.

18. Metody biohimicheskogo issledovaniya rastenij / A.I. Ermakov [i dr.]. L.: Agroprom-izdat, 1987. S. 41-45.

19. Dospekhov B.A. Metodika polevogo opyta (s osnovami statisticheskoj obrabotki rezul'tatov issledovanij). M., 1979. $463 \mathrm{~s}$.

20. Kolupaev Yu.E., Gorelova E. I., Yastreb T.O. Mekhanizmy adaptacii rastenij k gipotermii: rol' antioksidantnoj sistemy // Visnik Harkivs'kogo nacional'nogo agrarnogo universitetu. Seriya biologiya. 2018. № 1 (43). S. 6-33.

21. Ob ustojchivosti yabloni $\mathrm{k}$ neblagopriyatnym usloviyam zimnego perioda / N.G. Krasova [i dr.] // Sel'skohozyajstvennaya biologiya. 2014. № 1. S. 42-49. 